\title{
Infant Death and the Archaeology of Grief
}

\author{
Aubrey Cannon \& Katherine Cook
}

To build a theoretical and empirical foundation for interpretation of the absence, segregation or simplicity of infant burials in archaeological contexts, we review social theories of emotion, inter-disciplinary views on the relationship between mortality rates and emotional investment, and archaeological interpretations of infant burial patterns. The results indicate a lack of explicit theory in most archaeological accounts and a general lack of consideration for individual variation and the process of change in mortuary practice. We outline the tenets of Bowlby's attachment theory and Stroebe and Schut's dual process model of bereavement to account theoretically for pattern, variation and change in modes of infant burial. We illustrate the value of this psychology-based perspective in an analysis of Victorian gravestone commemorations of infant burials in 35 villages in rural south Cambridgeshire, England, where individual and class-based variation, relative to falling mortality rates, is best explained as a function of coping strategies and contextually based social constraint on the overt representation of grief and loss.

A role for grief in treatments of the dead may be assumed at some level, but there is little explicit theoretical foundation or empirical basis for linking particular forms of burial treatment to specific patterns of emotional experience. Historical contextual studies of death and burial (e.g. Stearns \& Knapp 1996; Tarlow 1999) provide insight into the emotional motivation underlying broad patterns of funerary behaviour, but their dependence on textual sources limits their archaeological application. Their focus on change as a consequence of shifts within a constellation of intertwined and inter-dependent circumstances and culturally structured attitudes also minimizes the role of individual differences in emotional experience and the importance of circumstances specifically related to material mortuary practice.

In the archaeology of infant death and burial, high mortality and emotional detachment have been cited to explain seemingly perfunctory disposal (Russell 1985, 49; Ucko 1969, 271) while careful interment has been attributed to particular emotional concern (Carroll 2011, 112; McLaren 2011, 96; Meskell
1999, 130-31). The potential for emotional variability is sometimes acknowledged (e.g. Carroll 2011; King 2000), but the presumed correspondence between burial mode and emotional experience is usually presented as if self-evident. Extensive historical and archaeological discussion of the possible relationship between infant mortality and parental attachment has offered little if any theoretical basis for explaining varied emotional or ritual response to infant death. Attachment theory (Bowlby 1969) and the dual process model of grief resolution (Stroebe \& Schut 1999), which account for variability in the experience and expression of grief, provide a way to fill this theoretical gap, and, in application, help to explain trends in infant commemoration in Victorian Cambridgeshire during a time of falling mortality. This specific case study illustrates empirically the capacity of psychological theory to account for individual and social response to infant death and mortality. More broadly, focus on the psychology of grief resolution acknowledges individual agency and historical circumstance in the creation of pattern and change in mortuary 
practice, and provides a more general explanation for the commonly observed absence, segregation and simplicity of infant burials, as well as the exceptional cases of more normative burial treatment.

\section{Archaeology of grief}

Emotion, as the motivational basis for human action (Joyce 2001, 21; Tarlow 1999, 27; 2000, 718-19), should be a key to understanding variable responses to death, and infant death in particular, but it is unclear how emotions should be conceptualized. Across anthropology, sociology, history and archaeology, researchers have explicitly distanced themselves from concerns with the individual psychological experience of emotion, focusing instead on the social construction of prevailing patterns of emotional expression. Leavitt (1996) refers to the collective idiom of expression, which differs from society to society, and among classes, genders, regions, and linguistic and ethnic groups. Others cite emotional styles (Middleton 1989), values (Tarlow 2000) or standards (Stearns \& Stearns 1985), and explain variation and change in relation to general social and historical circumstances. Stearns and Knapp (1996) apply an 'emotionological' approach to understanding transitions in the form and expression of grief, and cite the effects of a variety of social, religious and economic conditions and the role of published admonishments to observe prevailing standards.

Within archaeology, contextual analyses of historical cemeteries (e.g. Deetz 1977; Little et al. 1992; Parker Pearson 1982; Tarlow 1999) articulate similar associations among multiple variables to explain changing burial patterns. Parker Pearson (1982) described the shift toward restraint in mortuary practice in late nineteenth- and early twentieth-century England as the product of changes in religious beliefs, the medicalization of death and changing attitudes toward social display. Tarlow $(1999,140)$, in acknowledging the impossibility of selecting a prime mover to explain changes in responses to death and burial, noted that economic, social and ideological changes enabled and reinforced each other. She followed Stone (1977) in attributing change in mortuary practice to a pattern of affective individualism, described as the culmination of shifts in a whole system of values. Contextual explanations focus on the coherence among prevailing emotional standards, practices and broader historical circumstances, but generally do not provide a method to explain the process of change in how emotions are experienced and represented.

Most historians recognize individual variation from the emotional norm (e.g. Middleton 1989, 199;
Stearns \& Stearns 1985, 821; Strange 2005, 262), but Rosenwein $(2002,842)$ offers a more useful conceptualization of variability among overlapping emotional communities, which equate with social communities such as families, neighbourhoods and parish church memberships. People adjust their emotional displays as they move continually from one community to another, defining their circumstances and the nature of affective bonds, and evaluating the emotions of others and the modes of expression they expect, encourage, tolerate and deplore. She goes beyond debate over the roles played by individual psychology and social context to make two key points: 'not only does every society call forth, shape, constrain, and express emotions differently, but even within the same society contradictory values and models, not to mention deviant individuals, find their place' (Rosenwein 2002, 842-3, emphasis in original). These ongoing precedents for differences among subsets of individuals provide a basis for wider acceptance of alternative emotional standards. The question is, under what circumstances do different standards wax and wane in popularity?

Historical, ethnographic and archaeological accounts of negligible emotional expression or action in response to infant death have generated extensive discussion and debate over whether these deaths actually invoked feelings of grief, especially when mortality was high, but understanding variable response to infant death requires acknowledgement of the distinctions and inter-connections among the experience, expression and representation of emotion. The emotional experience of grief can be described as a function of attachment and loss (Archer 1999; Bowlby 1969; 1980; Shaver \& Fraley 2008). The expression of grief, which depends on the grief felt and social standards of appropriate behaviour, is the apparent indication of sadness and pain experienced as the result of loss (e.g. crying, withdrawal). The representation of grief then consists of the actions taken in response to feelings of loss, such as mourning, funerals and other ritual activity, burial and other treatments of the body, memorialization, talking about the experience of death and the deceased, or the avoidance of any action in relation to death. These strategies for coping with the experience of grief and the resolution of loss depend on the grief experienced, standards for its expression and individually and socially recognized capacities for effectively coping with grief.

\section{Infant death and the intensity of grief}

Early historical views on the relationship between emotional investment and infant mortality focused primarily on an individual psychological model of 
emotion and took an empathetic perspective in arriving at otherwise unsubstantiated conclusions. Ariès $(1962,39)$ characterized parents as indifferent toward the loss of infant children, which he explained as the direct and inevitable consequence of high birth and mortality rates. Shorter $(1975,200)$ argued more emphatically that before infant mortality declined, deep grief and mourning would have been psychologically crippling and even capable of destroying the social order. Stone $(1977,70)$ also argued that parents limited psychological involvement with their children to preserve mental stability while mortality rates remained high. Although he distanced himself from a self-described reductionist position that there was a simple and direct correlation between mortality and the degree of affect at any given moment of history, citing the importance of cultural norms and social expectations, Stone $(1977,81-2)$ clearly considered a lack of concern for small infants to be closely tied to poor expectations of their survival. Similar views extended to archaeology in the presumed association between perfunctory disposal and high infant mortality (Ucko 1969, 271).

Although Stone referenced the intervening variables of cultural norms and social expectations, he and others presumed a more or less universalist perspective on the emotions associated with infant death, which was challenged almost immediately on the basis of empirical evidence and a social constructionist theoretical perspective. Macfarlane (1981, 252, 255) cited literary, legal and autobiographical references to deep and tragic grief to refute Stone's suggested link between high mortality and emotional detachment, and expressed suspicion about demographic reductionism, which 'dismisses the vast effects of religion, ideology, social relations, economic and political forces, and assumes a direct and easily ascertained relationship between a specific demographic feature, mortality, and individual psychology'.

Other historians provided more detailed evidence that death commonly invoked intense grief among parents even in the context of high mortality rates. From her examination of English documents dating from the sixteenth through the nineteenth century, Pollock (1983) concluded there was no change in the capacity to experience emotional loss, though she noted that in every century infants were not mourned as deeply as young children. Dye and Smith (1986) documented similar attitudes among American mothers from the seventeenth through the twentieth century, and Jalland's $(1996,121)$ study of Victorian family diaries and letters led her to conclude there was no correlation between high mortality and any reduction in parental affection or the loss felt on the deaths of infants. Responding to cautions that such conclusions were based exclusively on writings of the social elite (Cannadine 1981), Strange (2005) found that child death also provoked intense distress among English working-class parents. She argues that improvised forms of burial, such as using soapboxes as coffins or slipping infants into the graves of others to avoid burial costs, represent a pragmatic resourcefulness, which enabled working-class families to retain all aspects of proper burial in spite of costs. She characterizes working-class responses to child death as the epitome of a pragmatic culture of bereavement, and describes subdued public response to bereavement as a coping mechanism. Other historical sources also show that intense grief was commonly experienced and expressed in the context of high infant mortality (e.g. Carroll 2011; Golden 1988; Rosenblatt 1983).

Archaeologists have used the evidence of careful burial to make the case that parents experienced some form of sadness and concern for infant children. Meskell $(1999,130-31)$ uses evidence of care in the burial of infants and other children at the Egyptian New Kingdom cemetery of Deir el Medina specifically to refute the still influential ideas of Ariès and others that suggested high mortality rates would lead parents to curtail emotional investment and limit ritual response to infant death. McLaren $(2011,96)$ makes the same case for Bronze Age southeast England, arguing that careful and central placement of infant and child burials beneath significant barrows and with grave goods indicates they were the subject of parental concern despite high mortality.

Although empirical evidence for deeply felt grief in the face of frequent infant death has undermined any notion of a universal relationship between high mortality and reduced emotional and ritual investment, there is growing empirical and theoretical support for variably contingent commitment to children. Strange (2005) acknowledged the ambiguities that often surrounded the relationships between parents, especially mothers, and their infant offspring, depending on factors such as social isolation and economic insecurity. Similar, but more detailed and better known, are the views of Scheper-Hughes (1992) on the responses of mothers to infants and infant death in Brazilian shanty towns. Her observation of what she described as indifference on the part of some impoverished women to the deaths of some of their infant children led her to examine the social and economic conditions responsible both for high rates of mortality and the sometimes indifferent attitude toward infant death and a superficially proper but abbreviated and uncaring ritual response. 
More recently, Hrdy (1999) developed a generalized, sociobiological perspective on this issue from observations of selective maternal neglect in a range of historical and ethnographic contexts. She argues that a mother's emotional commitment to her infant is highly contingent on ecological and historical circumstances, with poverty, war and the timing of pregnancy in relation to these and other circumstances among the conditions associated with abandonment, neglect or infanticide. She sees overall consistency in the emotional response to infants across historical and cultural differences, ranging between abandonment and total commitment.

The propensity for mothers and others to form attachments may be related to overall mortality rates, but is primarily a function of individual circumstance. Grief in response to infant death was widely experienced among all classes in Victorian England, and elsewhere, though the potential for detachment was also present, especially among individuals likely to experience hardship or to be, for any number of reasons, wary of attachment to unwanted or at-risk infants. Different social or emotional communities can also express grief in different ways, as Strange (2005) noted for the English middle and working classes, and documented cases show that individuals also coped with grief in varying ways, sometimes in contrast to the prevailing standards of their main emotional communities.

Whether infant mortality rates should have any predictable effect on the experience, expression or representation of grief remains unresolved. If high infant mortality increases the likelihood of parental detachment, social repression of emotional expression or both, then it is likely also to be associated with lesser representation of grief, as in monumental commemoration or other forms of formal mortuary ritual. If declining mortality rates increase the likelihood of attachment to infants, then the resulting experience of grief would lead to dissonance with its social suppression and subsequently lead to change in emotional standards. Alternatively, as seems more likely, if grief was widespread even in the context of high mortality, then social standards that worked to suppress its expression might still have reason to change as mortality declined. The less frequent experience of grief could result in more open expression and representation if in these circumstances it was less likely to rekindle grief in others. ${ }^{1}$

\section{Archaeological views of infant burial}

Although the differential treatment and frequent absence of children and especially infants in archae- ological burial populations is commonly noted and discussed, explanations have not developed much beyond the early views of Binford (1971) and Saxe (1970), which were geared toward establishing a basis for inferring broader principles and patterns of social organization. They accounted for the frequent absence and, where present, spatial segregation of infants, particularly through burial within or near houses, as a function of the extremely limited social relationships of young children and infants. Since the lives and deaths of infants presumably had little impact beyond the immediate family, the rites associated with their deaths were thought to be similarly restricted to the family, with burial taking place within the precincts of the family living area or outside of the living area of the wider society altogether (Binford 1971, 22).

Although there is widespread consensus that the deaths of infants garner less public notice or social engagement than the deaths of older children and adults (Dye \& Smith 1986, 346; Hertz 1960, 84; Peppers \& Knapp 1980, 28, 145-6), it is not clear that this should restrict public representations of family grief. The practice in Western contexts to bury perinates and neonates in areas reserved for them and without any marker to preserve their memory is increasingly being challenged by grieving parents (Bleyen 2010, 76; Peelen 2009; Scott 1999, 26-7). More than just the passive effects of a lack of social concern are required to explain social standards that constrain representations of grief.

Segregation and restraint with regard to infant burial are widespread throughout archaeological history, but there are often examples of infants accorded the location and treatment generally evident in older child and adult burials, even when the majority of infants are given distinctive and typically simplified mortuary treatment (e.g. Crawford 2011; Storey \& McAnany 2006). In some cases, these may be infants whose death, by virtue of their own or their family's status, garnered a greater degree of community involvement, as Binford and Saxe each seemed to suggest. Alternatively, they may represent deaths of little concern beyond immediate family members, who chose to accord the infant an elaborated or typically adult mortuary treatment because they possessed the means and the will to defy tradition to express their own perception of the value and loss of the deceased infant. There are also rare archaeological contexts in which infants share a broader, more normative mode of burial in numbers proportional to expected mortality rates. Scott $(1999,90)$ cited one example from the British Iron Age-Roman Period site of Owslebury (Collis 1977), in which infants accounted for nearly 35 per cent of recorded burials, suggesting they all 
received normative mortuary treatment. An example from the Preceramic Peruvian village of Paloma shows similar high proportions and normative treatments of infant burials, including grave goods of exotic materials (Quilter 1989). The purpose of restraint and segregation, and the reasons for exceptions and more normative infant burial require more specific explanation than is entailed in conceptions of limited social value.

Archaeological explanation most commonly refers to cultural definitions of personhood to explain different modes for infant burial. Based on widespread ethnographic observation and some contemporary Western views, the argument is that infants must survive to achieve culturally determined developmental milestones before they are recognized as substantial or full persons warranting the mortuary ritual normally accorded adults (Rubertone 2001, 140-48; Scott 1999, 90; Ucko 1969, 271). Although widely cited, archaeological use of this explanation is somewhat circular, since the only evidence infants were not accorded full personhood is their absence from or differential presence in burial populations. It also assumes passive acceptance and reproduction of cultural norms, without explaining their origin or motivations for their maintenance.

Theoretically and empirically unsupported references to definitions of personhood, the social value of infants or relative detachment in the face of high infant mortality provide weak explanation for the typically simple treatment or segregation of infant burials and fail to account for the few examples of exceptional investment and proportional representation that have been observed archaeologically. An alternative focus on the psychology of grief, especially strategies for coping with grief, provides a potentially more comprehensive theory-based account of variation and change in the mortuary treatment of infants, particularly in response to variable and changing historical circumstances.

\section{Attachment theory and the dual process model of bereavement}

Bereavement is a very complex phenomenon and the focus of extensive research, primarily from the perspectives of psychology and sociology. Based on hundreds of clinical studies and increasing awareness of the influence of social and cultural context on the meaning and experience of bereavement, researchers have focused attention on three main alternatives to the now widely discredited Freudian emphasis on grief work. These include the cognitive stress perspective, which emphasizes subjective evaluations of the difficulties surrounding loss, and the trauma perspective, which stresses the challenges to a survivor's sense of self and their place within the world (Bonanno \& Kaltman 1999, 763-7), but by far the most influential psychological perspective has been attachment theory (Bowlby 1969; 1980), which posits a biological basis for individual variability in the experience of loss and ways of coping with grief. If an attachment has been forged, loss is felt regardless of social and cultural constructs or individual understandings of the meaning of that loss, and individual adjustments must be made to accept the loss and its consequences. The dual process model of bereavement takes this further in describing individual variation in coping behaviour (Stroebe \& Schut 1999).

John Bowlby's (1980) theory of loss, grief and mourning, recognized as the deepest and most comprehensive of the major theories of bereavement (Shaver \& Fraley 2008, 70), posits that the anxiety response activated upon separation, which has been selected for in the course of evolution to induce infants to maintain proximity to the security of caregivers, is activated in adults in response to separation resulting from death. The selection for an innate tendency to resist prolonged separation from any attachment figure and to react anxiously when separation and loss occur creates a drive to re-establish contact, but in the case of death this is physically impossible. As a result, individuals must go through a process of adjustment to their inner working models of themselves and their place in the world to accept the permanence of the physical separation, re-establish their lives and reconfigure a relationship with the deceased that does not depend on their ongoing living presence (Shaver \& Fraley 2008, 64-5). Since attachments can also form early in pregnancy, loss to miscarriage, stillbirth or early infant death can trigger the same type of loss reaction encountered in any attachment relationship (Robinson et al. 1999).

Bowlby observed that grief is experienced differently by people who exhibit different styles of attachment, which are characterized in relation to dimensions of anxiety and avoidance (Mikulincer \& Shaver 2008, 88, 90; Shaver \& Fraley 2008, 56). Researchers recognize fine scales of variation along these two dimensions, but commonly refer to attachment styles as more or less secure, anxious or avoidant. Secure attachment is associated with what might be considered normal grieving and gradual adjustment to the loss and changed circumstances that result from death (Stroebe et al. 2005, 61). Anxiously attached people are likely to experience intense anxiety, fail to accept the loss and have difficulty establishing a new life (Shaver \& Fraley 2008, 58), while people described 
as avoidant are likely to suppress anxiety and avoid thoughts of the deceased. Outwardly, they show little sign of grieving, though the absence of grief may lead to later health problems and unwanted reactivation of painful thoughts (Shaver \& Fraley 2008, 59-62; Stroebe et al. 2005, 61). The importance for archaeology is that differences in bereavement styles are also related to ways of coping with loss that may be evident in material representations.

The dual process model of bereavement (Stroebe \& Schut 1999) posits that grieving works typically and most effectively as a process of alternating between a focus on the loss experience, thinking about and yearning for the deceased, and efforts to adjust to the substantial changes brought about by the loss. Stroebe and Schut recognized that individuals varied in the extent to which they were loss- or restoration-oriented, which they explained in relation to Bowlby's attachment theory. Securely attached individuals grieve, but not unduly, and attend to the other stressful circumstances necessary for moving on with their lives (Stroebe et al. 2005, 61). They move flexibly between loss-oriented and restoration processes. Individuals tending toward anxious forms of attachment focus more on loss and are subject to the complications of chronic grieving as a result. They might become preoccupied with thoughts of the deceased and pay little attention to the tasks involved in restoring their lives. Individuals described as avoidant tend to focus on restoration.

Beyond their clinical applications, attachment theory and the dual process model have been used from the outset to characterize broader differences in grief and mourning strategies between cultures. Stroebe and Schut $(1999,204)$ cited Wikan's (1988) study of Egyptian and Balinese responses to death as illustration of cultures at opposite ends of loss- and restoration-oriented patterns. They describe the Muslim community on the island of Bali as restorationoriented because people there show no overt signs of grief and endeavour to continue with daily life as if the loss had not occurred. In the Egyptian case, grief is expressed openly and there is a shared focus on memory of the deceased. When a child dies, mothers are expected to enter a period of mourning that may last for months (Wikan 1988, 452). In contrast, in Bali when a child dies close family members will restrain their expressions of sadness. Wikan $(1988,455)$ argues that the experience of grief does not necessarily differ much between the two cultures, despite the fact they exhibit diametrically different patterns of coping with loss. Researchers are only beginning to explore cultural variation in the relationship between attachment styles and grief, but the limited cross-cultural evidence available so far shows a predictable relationship between attachment styles and strategies for maintaining or breaking connections with the dead (Gassin 2010), though the importance of worldviews and the variable meanings of death and grief in different cultures are widely acknowledged (e.g. Rosenblatt 2008).

The combination of attachment theory and the dual process model of bereavement offers a powerful explanation for the variation in grief and coping strategies documented in Western and other cultural contexts, and provides a basis for understanding mortuary patterns observed archaeologically. Mortuary practices normally include elements of both loss and restoration orientation, but some practices, such as monumental commemoration, place more emphasis on loss. Archaeology may be better positioned to see variation in coping strategies than the emotion of grief itself. In contrast to social standards of emotional expression, the workings of which may be difficult to discern, coping strategies are inherently variable and flexible among individuals and within and between cultural and historical contexts. It is that variability and flexibility on the part of individuals that creates the potential for change in treatments of the dead. The interpretation of loss- or restoration-orientation in such treatments is never likely to be simple or unequivocal in archaeological contexts, but the extent to which placement and reminders of the dead are created and maintained in locations in which they are likely to be encountered on a regular basis can be taken as one measure of the degree of loss-orientation.

Segregated burial of infants could be interpreted as a way to reduce encounters with the location and memories of the dead as part of a more restorationoriented strategy, while burial within the context of daily activity, such as in or near the house or in a community cemetery would be consistent with greater loss-orientation. Certainly the commemoration of infants on churchyard memorials seems overtly designed to keep their memories alive and as a way to maintain long-term focus on their loss. Use of this loss-oriented strategy does not imply its effectiveness or ineffectiveness in coping with grief. Memorials of all kinds are recognized as aiding in the process of continuing a relationship with the dead while also reorganizing one's life to accommodate the $\operatorname{loss}^{2}$ (Mikulincer \& Shaver 2008, 94). Nonetheless, there is some limited evidence to suggest a restoration strategy can be more effective in the case of infant death, potentially resulting in social pressures to conform to such a strategy even when it is inconsistent with the experience and desire of a grieving parent. Grief research has also found that in most Western contexts men tend 
to be more restoration-oriented, while women are oriented more toward thinking about the loss of the child (Wijngaards-de Meif et al. 2008).

Differences in coping strategies create the potential for conflict, even extending beyond individuals sharing common grief at the loss of an infant, since any reminder of the loss can be a powerful trigger for recurring grief. Grave visits, for example, often produce conflict for parents in contemporary Western contexts (Peppers \& Knapp 1980, 129). Some mothers will regularly visit graves, while others will not go at all. Some seek to avoid the cemetery entirely, and are conflicted when required to attend a burial service for someone else. Avoidant individuals and those that are chronically bereaved as the result of an anxious style of attachment are generally more subject to recurrent grief (Mikulincer \& Shaver 2008, 100; Rosenblatt \& Hammer Burns 1986, 238). In the context of high infant mortality, stimuli apt to be distressing to others who have experienced similar loss might be almost ubiquitous if every infant death was the subject of overt public ritual, burial and memorial. ${ }^{3}$

Social pressures and the normal benefits of restoration-oriented coping strategies might then account for the patterns observed in most archaeological contexts, in which the 'majority of infant dead appear to have been buried outside cemeteries and settlements, and remain undiscovered and unrecovered by archaeology' (Scott 1999, 107, emphasis in original). The real desire on the part of some individuals to exercise their need for loss-orientated activities in coping with the grief of losing an infant can explain the common occurrence of exceptional infant burials, while the potential for change in circumstances that might ease social pressure to maintain restoration orientation always holds the possibility for broader change in the pattern of infant burial.

Attachment theory and the dual process model of bereavement predict individual variation in coping strategies and can explain exceptional mortuary treatments, such as proximate and elaborate burials and memorials, as consistent with greater loss orientation. Social constraint on public ritual and memorialization might result from a widespread desire to maintain a restoration-oriented coping strategy by avoiding intrusive reminders of one's own loss through witnessing public expressions and representations of grief on the part of others. Although some, if not most individuals in these circumstances might receive therapeutic benefit from memorials as physical manifestations of a continuing bond with the dead infant, they would be constrained by the potential impact on the grief responses of others. A reduction in infant mortality could lead to the relaxation of social constraints by re- ducing the numbers of recently bereaved parents potentially subject to renewed grief, and the numbers of ritual or memorial representations that might rekindle their grief. This range of theoretically predicted individual and social response to infant death and declining mortality is illustrated empirically in the commemorations recorded in the Victorian churchyards of rural south Cambridgeshire.

\section{Infant mortality and commemoration in Victorian south Cambridgeshire}

Gravestones can serve variously as media for social display (Parker Pearson 1982), the representation of identity (Mytum 2009) or the expression of religious sentiment (Deetz 1977), but their use is predicated in the first instance by death (Tarlow 1999, 24) and the choice of survivors to respond to this loss through lasting commemoration. The enduring remnants of these actions found today in churchyards and cemeteries record a diverse array of information concerning changing conditions and cultural perspectives, including responses to infant death in the context of declining mortality. Rural settings, in particular, provide a socially diverse but manageable range of dimensions from which to analyse patterns and trends in mortality and burial patterns, and rural south Cambridgeshire, previously the focus of Cannon's (1989; 2005) studies of social trends in gravestone commemoration, provided ready access to pertinent data in the form of census, baptism, burial and monument inscription records. Complete sets of these records allowed for comparison of infant mortality rates over the course of the entire nineteenth century for 35 villages (Fig. 1). Census and monument records from 1851 to 1900 allowed further insight into mortality and commemoration rates by social class and over time.

In common with much of rural Victorian England, Cambridgeshire's agricultural economy was focused mainly on grain production on large farms, in this case largely operated by tenant farmers who rented land from the landholding colleges of Cambridge University. There was also a variety of smaller farms throughout the county and a small number of large farms owned by resident farming families, though these were the exceptions. Villages also supported a variety of trades and craftspeople, but the vast majority of parish residents were agricultural labourers. Along with the rest of England, rural Cambridgeshire experienced dramatic population growth from the beginning through to the middle of the nineteenth century, followed by significant population decline as the result of urban migration and reduced 


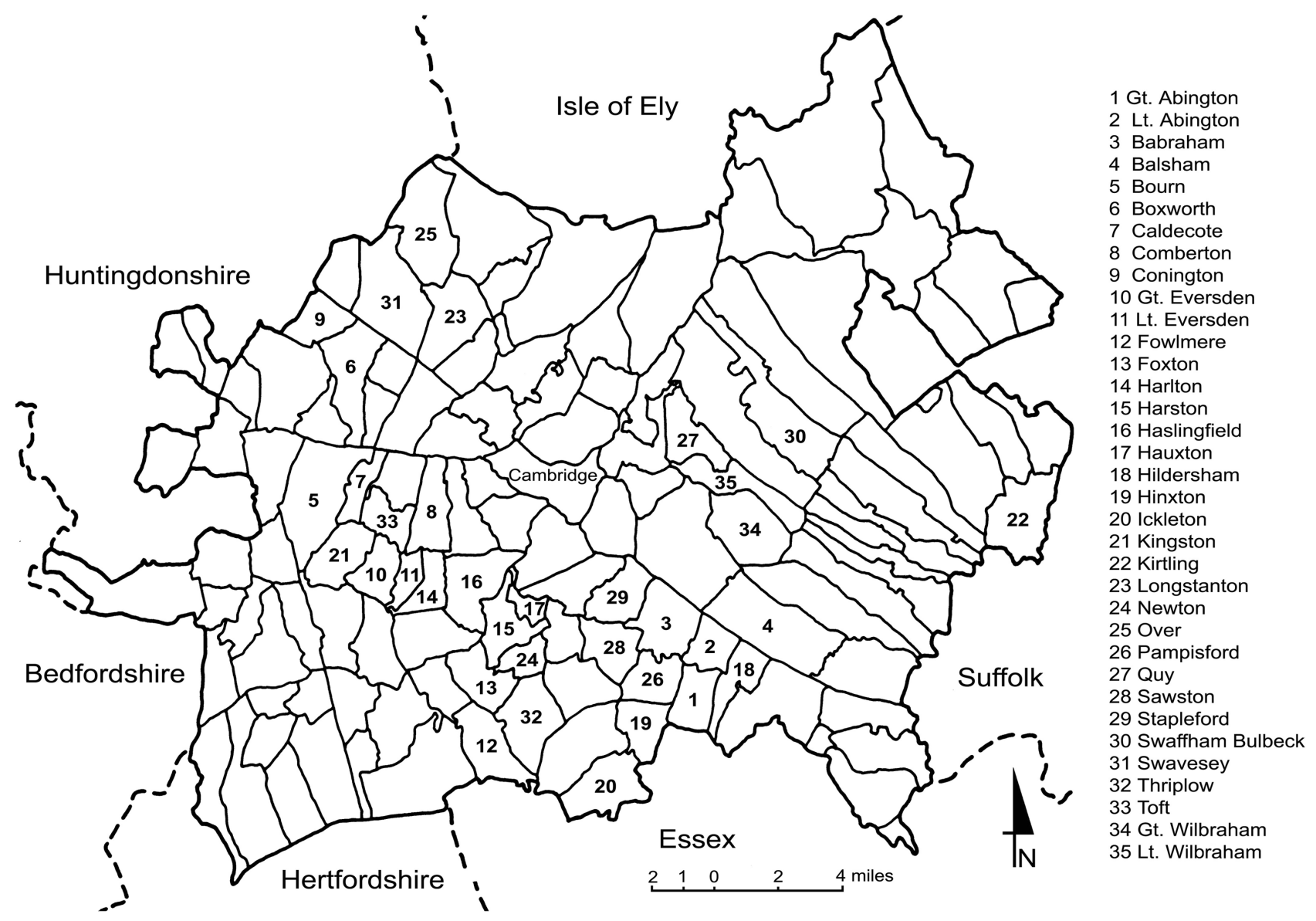

Figure 1. Cambridgeshire parishes included in the study.

birth rates. The prosperity of tenant farmers also peaked toward the middle of the century, and many supported multiple domestic servants at this time. An agricultural depression beginning in the early 1870s reduced the fortunes of most farmers, but the economic circumstances of labourers continued to improve gradually throughout the course of the century (Horn 1984; Howkins 1991).

High infant mortality in England and Wales, which had been fluctuating between 100-200 deaths per 1000 live births for centuries, began to decline in the latter half of the nineteenth century, though even more dramatic declines took place in the early part of the twentieth century (Gregory 2008, 774). Rates declined earlier and faster in rural areas of southern and southeastern England than in urban or peripheral rural areas to the north, and Cambridgeshire is located in the core of the area that saw the fastest and most dramatic early decline. Gregory $(2008,792)$ suggests this pattern may be attributable to agricultural improvements, reduced fertility, changes in disease patterns or some other factors, though there is some agreement that declining fertility led to important improvements in infant nutrition and care (Winter 1982, 115).

We use baptism and burial records as surrogates for birth and death data to calculate relative mortality rates over time. Our analysis of baptisms, burials and monumental commemorations is based exclusively on Church of England parish registers and the monument inscription records of parish churchyards recorded by members of the Cambridgeshire Family History Society (CFHS). ${ }^{4}$ Baptism and burial records were available in searchable digital format from CFHS transcriptions of the originals. Searchable records of the decennial censuses from 1851-1901 were accessed online through ancestry.co.uk.

There is a vast discrepancy between the numbers of burials recorded in parish registers and the number of commemorations evident on extant monuments. The total number of burials recorded for the period $1851-1900$ is 13,658 . Only 2052 (15 per cent) of these burials were commemorated in the monument inscriptions recorded by the CFHS. Attrition has 
undoubtedly affected the number of extant stone monuments, but the vast majority of burials were never commemorated on a gravestone. A variety of wooden and painted metal markers were in use throughout the nineteenth and early twentieth centuries and have since been lost, though isolated wooden markers dating to 60 years earlier were still present in a few churchyards in the mid 1980s. Stone monuments represent a particular and lasting mode of commemoration that involved greater financial investment, but memorials made of more perishable materials would have been as effective and meaningful as ways to cope with loss and grief. Our data and analyses therefore do not encompass the totality of loss orientation represented by burial markers, but we think the relative rates of gravestone commemoration for infants and others, by social class and over time, are representative of more general trends.

To assess the effect of socioeconomic contexts on mortality and commemoration rates, we tallied frequencies of baptisms, burials and monument inscriptions according to occupation categories available from census records. We collapsed the wide range of specific occupations into three broad class divisions: (1) upper-middle class, consisting mostly of large-scale tenant farmers and their families, as well as clergy and a very small number of other professionals; (2) lower-middle class, consisting of a wide array of trades and craftspeople and their families, as well as smaller-scale farmers; and (3) lower class, consisting overwhelmingly of agricultural labourers but also including small numbers of other semi-skilled labourers and their families.

There are many issues involved in using baptism and burial records as direct measures of births and deaths (Wrigley \& Schofield 1981) and in the assignment of occupation categories to particular socioeconomic groups (Armstrong 1972), but these problems, though important for social history and demographic studies, are unlikely to create spurious patterns of association between commemoration and mortality. The greater likelihood is that assignment errors or missing data would reduce the apparent clarity of patterns that are present. The large volume of data and its distribution across thirty-five parishes give further confidence in our results. The quantity and quality of the data certainly exceed those typically available for archaeological interpretation by many orders of magnitude.

\section{Analysis and interpretation}

\section{Mortality rates}

Infant mortality rates were consistent for most of the nineteenth century, and then declined over the last

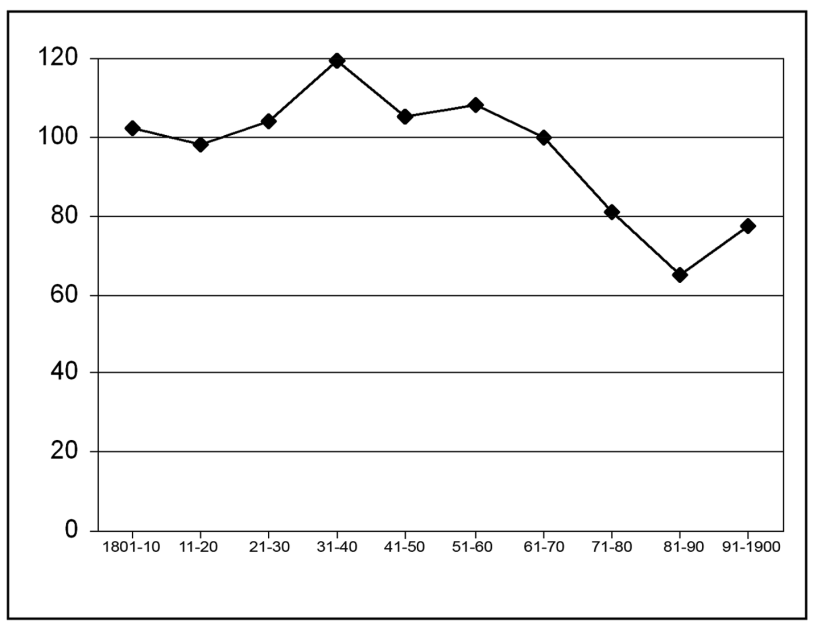

Figure 2. Infant ( $<1$ year old) mortality rates [(infant burials/infant baptisms) $\times 1000$ ] by decade, 1801-1900.

Table 1. Infant $(<1$ year old) mortality rates by social class and decade, 1851-1900.

\begin{tabular}{|l|c|l|l|}
\hline & Upper-middle & Lower-middle & Lower \\
\hline $1851-60$ & 84.6 & 116.3 & 107.5 \\
\hline $1861-70$ & 141.0 & 98.7 & 98.0 \\
\hline $1871-80$ & 43.5 & 76.9 & 84.2 \\
\hline $1881-90$ & 55.3 & 51.9 & 70.1 \\
\hline $1891-1900$ & 92.6 & 65.4 & 75.8 \\
\hline
\end{tabular}

Table 2. Comparison of infant ( $<1$ year old) mortality by social class, 1851-70, 1881-1900.

\begin{tabular}{|l|l|l|l|}
\hline & Upper-middle & Lower-middle & Lower \\
\hline $1851-1870$ & 111.8 & 107.1 & 102.7 \\
\hline $1881-1900$ & 72.0 & 58.3 & 72.7 \\
\hline
\end{tabular}

three decades (Fig. 2). Calculations by decade and social class for the period 1851-1900 show roughly the same trend across social classes, though with some variation in the scale and timing of decline in the latter part of the century (Table 1). Although the rates per decade are somewhat volatile for the upper-middle class, likely due to smaller sample sizes, the overall mortality rate is roughly comparable for all social classes in the period 1851-1870, and then shows the beginning of a decline in the following decade. Combining the figures into broader periods reduces some of the volatility due to small numbers (Table 2). Although rates were declining by $1871-1880$, we compare the values for 1851-1870 to those for 1881-1900, since falling rates in the decade between are unlikely to have been consciously perceived as a change in circumstance. The data show infant mortality was roughly comparable across classes in both periods and much lower in 1881-1900, though there are no objec- 
Table 3. Percentage of burials commemorated on gravestones [(commemorations/burials $) \times 100]$ by social class and decade, 1851-1900.

\begin{tabular}{|l|l|l|l|}
\hline & Upper-middle & Lower-middle & Lower \\
\hline $1851-60$ & 50.2 & 17.2 & 2.5 \\
\hline $1861-70$ & 63.5 & 23.1 & 4.5 \\
\hline $1871-80$ & 61.1 & 29.3 & 5.1 \\
\hline $1881-90$ & 64.3 & 29.1 & 7.0 \\
\hline $1891-1900$ & 69.7 & 37.3 & 9.1 \\
\hline
\end{tabular}

tive standards for gauging perceptions of the decline. Rates continued to fall, and in comparison to the mid twentieth century were still very high in 1881-1900. Infant mortality was much lower for the generation bearing children in the late nineteenth century than it had been for any immediately ancestral generation, but a dramatic shift in the experience, expression or representation of grief might not be evident unless grief and the manner of coping with grief were closely aligned with the frequency of infant death.

\section{Monumental commemoration}

Although only 15 per cent of late nineteenth-century burials are commemorated on extant gravestones, that percentage varies over time and differs markedly between social classes (Table 3). Not surprisingly, it is highest for the upper-middle class, much lower for the lower-middle class and very low for the lower class, though the latter rate rises steadily through the century. Proportional representation of burials on stone monuments appears to be tied most clearly and simply to economic means. This is evident in the differences between classes, but also appears to have affected changes over time. The use of monuments by large-scale farmers increased with rising prosperity in the middle part of the century and remained steady thereafter. The lower-middle and lower classes saw their economic fortunes improve over the latter part of the century and this is evident in the increasing representation of their burials. In adopting monumental commemoration, lower-class individuals were increasingly following a practice already well established among the more prosperous members of rural society.

Commemoration rates also vary according to the age of the deceased. Figure 3 shows the number of burials and the number and percentage of commemorations by yearly age increments. Rates are very low for infants and young children, but higher for older children and young teens. They continue to rise for older teens and young adults, and peak for middleage adults before falling slightly for adults over the age of 70 . Infants under the age of one are the largest
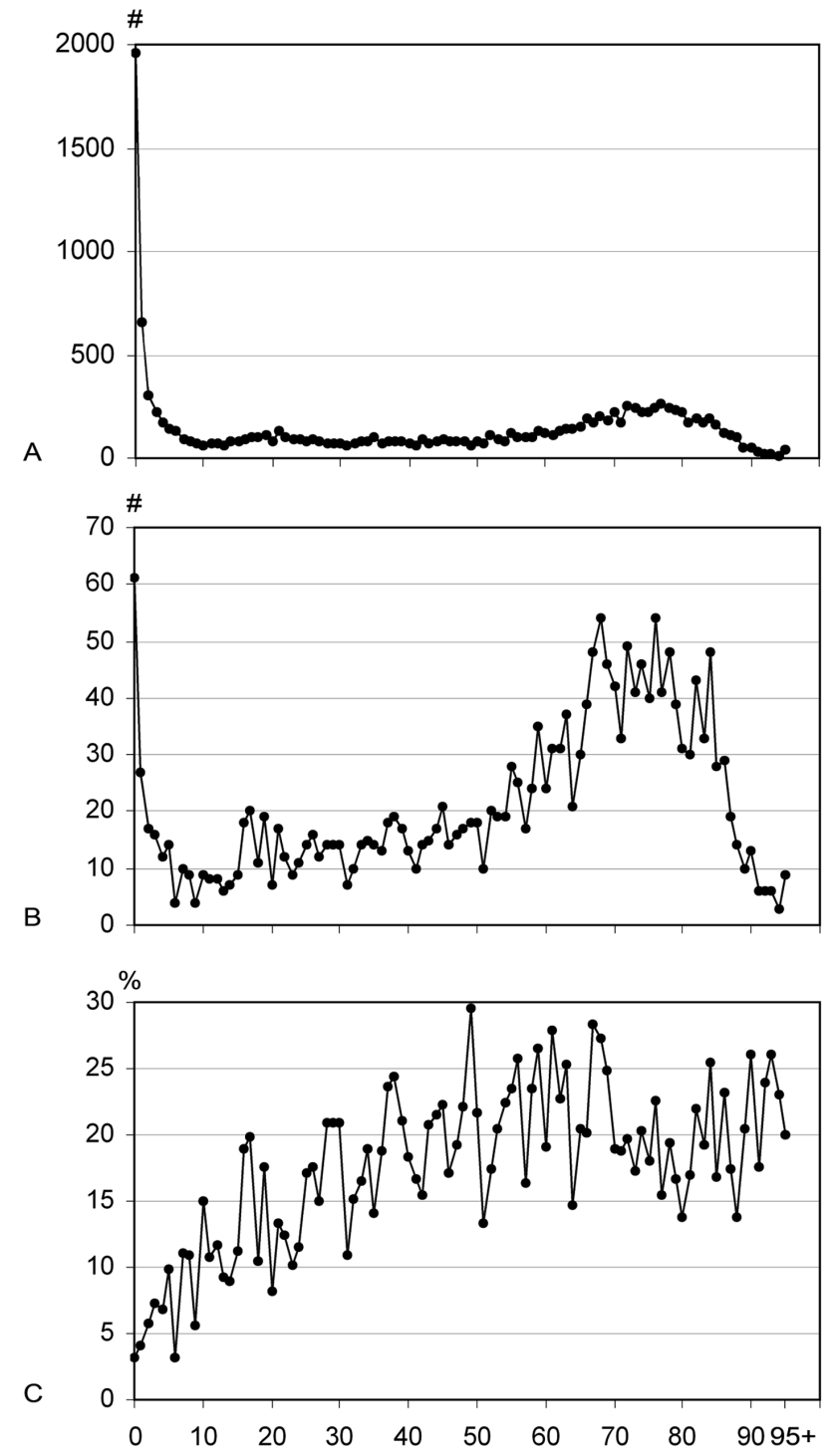

Figure 3. A) Number of burials; B) number of burials commemorated; and $C$ ) percentage of burials commemorated by annual age increments, 1851-1900.

single age category buried in the period 1851-1900, yet only 61, or 3.1 per cent, of the 1959 infants buried were recorded on gravestones, the lowest rate of any single age category. The rates for annual age increments show a slight increase to 4.6 per cent for one- and two-year-olds before a jump to 7.3 per cent for threeyear-olds, which is close to the 8.5 per cent recorded for all children 3-14 years in age. Based on this shift for children older than two, we chose to examine trends for infants less than one year of age and all those under the age of three. The inclusion of oneand two-year-olds in our mortality and commemoration figures also reduces the volatility of some trends over time, particularly for the small numbers of 
Infant Death and the Archaeology of Grief

Table 4. Gravestone commemoration rates by age group, decade and social class compared to infant and child mortality rates [calculated as (burials/baptisms) $\times 1000$ ].

\begin{tabular}{|c|c|c|c|c|c|c|c|c|c|c|c|c|c|}
\hline & \multicolumn{8}{|c|}{$\begin{array}{c}\text { Commemorations/Burial (C/B) and \% Commemorated } \\
\text { by Age Group }\end{array}$} & \multicolumn{5}{|c|}{$\begin{array}{l}\text { Baptisms (Bap), Burials (B) } \\
\text { and Mortality Rates (MR) }\end{array}$} \\
\hline & \multicolumn{2}{|c|}{$<1 \mathrm{yr}$} & \multicolumn{2}{|c|}{$<3$ yrs } & \multicolumn{2}{|c|}{ 3-14 yrs } & \multicolumn{2}{|c|}{$15+$ yrs } & \multicolumn{3}{|c|}{$<1 \mathrm{yr}$} & \multicolumn{2}{|c|}{$<3$ yrs } \\
\hline & $\mathrm{C} / \mathrm{B}$ & $\%$ & C/B & $\%$ & $\mathrm{C} / \mathrm{B}$ & $\%$ & C/B & $\%$ & Bap & B & MR & B & MR \\
\hline \multicolumn{14}{|c|}{ Upper-middle } \\
\hline $1851-60$ & $5 / 22$ & 22.7 & $11 / 32$ & 34.4 & $9 / 19$ & 47.4 & $102 / 192$ & 53.1 & 260 & 22 & 84.6 & 32 & 123.1 \\
\hline $1861-70$ & $10 / 34$ & 29.4 & $14 / 45$ & 31.1 & $9 / 14$ & 64.3 & $163 / 234$ & 69.7 & 241 & 34 & 141.0 & 45 & 186.7 \\
\hline $1871-80$ & $2 / 10$ & 20.0 & $2 / 16$ & 12.5 & $6 / 8$ & 75.0 & $116 / 179$ & 64.8 & 230 & 10 & 43.5 & 16 & 69.6 \\
\hline $1881-90$ & $1 / 11$ & 9.1 & $3 / 20$ & 15.0 & $3 / 6$ & 50.0 & $104 / 145$ & 71.7 & 199 & 11 & 55.3 & 20 & 100.5 \\
\hline 1891-1900 & $7 / 12$ & 58.3 & $9 / 16$ & 56.3 & $3 / 6$ & 50.0 & $96 / 133$ & 72.2 & 162 & 15 & 92.6 & 19 & 117.3 \\
\hline \multicolumn{14}{|c|}{ Lower-middle } \\
\hline $1851-60$ & $6 / 111$ & 5.4 & $9 / 152$ & 5.9 & $9 / 65$ & 13.8 & $114 / 549$ & 20.8 & 972 & 113 & 116.3 & 154 & 158.4 \\
\hline $1861-70$ & $6 / 103$ & 5.8 & $8 / 150$ & 5.3 & $14 / 82$ & 17.1 & $159 / 553$ & 28.8 & 1044 & 103 & 98.7 & 150 & 143.7 \\
\hline $1871-80$ & $4 / 72$ & 5.6 & $15 / 114$ & 13.2 & $11 / 66$ & 16.7 & $209 / 622$ & 33.6 & 936 & 72 & 76.9 & 114 & 121.8 \\
\hline $1881-90$ & $4 / 43$ & 9.3 & $8 / 81$ & 9.3 & $4 / 36$ & 11.1 & $163 / 495$ & 33.6 & 887 & 46 & 51.9 & 86 & 97.0 \\
\hline 1891-1900 & $5 / 43$ & 11.6 & $8 / 71$ & 9.8 & $13 / 35$ & 37.1 & $185 / 447$ & 41.4 & 810 & 53 & 65.4 & 82 & \begin{tabular}{|l}
101.2 \\
\end{tabular} \\
\hline \multicolumn{14}{|c|}{ Lower } \\
\hline $1851-60$ & $2 / 439$ & 0.5 & $3 / 636$ & 0.5 & $5 / 321$ & 1.6 & $47 / 1258$ & 3.7 & 4074 & 438 & 107.5 & 636 & 156.1 \\
\hline $1861-70$ & $1 / 409$ & 0.2 & $2 / 622$ & 0.3 & $7 / 244$ & 2.9 & $85 / 1232$ & 6.9 & 4163 & 408 & 98.0 & 621 & 149.2 \\
\hline $1871-80$ & $5 / 312$ & 1.6 & $6 / 467$ & 1.3 & $9 / 180$ & 5.0 & $84 / 1305$ & 6.4 & 3706 & 312 & 84.2 & 467 & 126.0 \\
\hline $1881-90$ & $1 / 181$ & 0.6 & $3 / 274$ & 1.1 & $3 / 99$ & 3.0 & $96 / 1089$ & 8.8 & 2682 & 188 & 70.1 & 282 & 105.1 \\
\hline 1891-1900 & $2 / 157$ & 1.3 & $4 / 220$ & 1.8 & $2 / 76$ & 2.6 & $117 / 1052$ & 11.1 & 2256 & 171 & 75.8 & \begin{tabular}{|l|}
232 \\
\end{tabular} & 102.8 \\
\hline
\end{tabular}

upper-middle-class burials and lower-class commemorations (Table 4).

Mortality rates are virtually identical across social classes for each decade of the century, with the exception of the very low numbers of upper-middleclass burials in 1871-1880, and the unusually high numbers in 1861-1870, both of which can be attributed to the smaller sample for this class. Commemoration rates for infants and for all children under the age of three are strikingly different between social classes, being highest for the upper-middle class and virtually nil for the lower class. This overall difference is clearly a function of economic means, but there are changes in rates within classes that are not as easily explained.

Upper-middle-class commemoration of burials of children under the age of three is virtually unchanged between the periods 1851-1870 and 18811900 (Table 5), despite decline in infant and child mortality rates. For this class, burial investment in children is unrelated to mortality. In contrast, both the lowermiddle and lower classes show substantial increases in infant and young child commemoration. Despite the correlation of these latter trends with declining infant mortality, the rate of increase also has to be considered in the context of general increases in rates across all age categories. For the upper-middle class, mon-
Table 5. Infant and young child burials ( $<3$ years of age) as a percentage of all burials compared to the commemoration rates of infant and child burials and adult burials $(15+$ years of age) by social class, 1851-1870, 1881-1900.

\begin{tabular}{|c|c|l|l|}
\hline & Burials <3/All Burials & $<3$ Comm. & 15+Comm. \\
\hline \multicolumn{4}{|c|}{ Upper-middle } \\
\hline $1851-1870$ & $77 / 537(14.4 \%)$ & $32.5 \%$ & $62.2 \%$ \\
\hline $1881-1900$ & $39 / 338(11.0 \%)$ & $33.3 \%$ & $71.9 \%$ \\
\hline \multicolumn{4}{|c|}{ Lower-middle } \\
\hline $1851-1870$ & $304 / 1553(19.5 \%)$ & $5.6 \%$ & $24.8 \%$ \\
\hline $1881-1900$ & $168 / 1202(13.1 \%)$ & $10.5 \%$ & $36.9 \%$ \\
\hline \multicolumn{5}{|c|}{ Lower } \\
\hline $1851-1870$ & $1263 / 4323(29.2 \%)$ & $0.4 \%$ & $5.3 \%$ \\
\hline $1881-1900$ & $519 / 2877(17.6 \%)$ & $1.4 \%$ & $9.9 \%$ \\
\hline
\end{tabular}

umental commemoration for adults (aged 15+ years) shows a modest increase unmatched by any increase for infants and young children. For the lower-middle class, there is a larger increase in adult commemoration, but the increase for infants and young children is proportionately greater. For the lower class, the adult rate almost doubles, but the rate for children, though extremely low, more than triples.

These data indicate a disproportionate increase in the monumental commemoration of infants 
and young children among the lower-middle and lower classes. Since declining mortality rates were equivalent across social classes, the effect, if any, appears to have been felt only by members of these lower classes. A possible explanation is that infant commemoration was already at a saturation point among members of the upper-middle class by the mid nineteenth century. The proportion of individuals in this group that found a measure of comfort in the more loss-oriented coping strategy of gravestone commemoration was already engaged in the practice without regard for the rate of infant mortality. Members of this social class may also have been under less social constraint within their immediate emotional community and less concerned with the standards of other class-based communities within their home villages. It appears the decline in infant mortality had a greater effect on members of the lower-middle and lower classes, but probably not because they disproportionately became more willing to invest emotionally in infants. Rather, it was the greater effect of reduced mortality within the context of other demographic changes. The proportion of upper-middle-class burials consisting of children under the age of three declined only slightly between 1851-1870 and 1881-1900 (Table 5). For the lower-middle class, the decline was somewhat greater, but was much greater for the lower class. The population of labourers and their families, making up the lower class of rural society, was both much smaller and older by the end of the century. Average family size was also smaller. The absolute and relative numbers of infant and child deaths in this group were therefore much lower than in earlier decades. This decline in the relative frequency of infant death matches the proportionately greater increase in gravestone commemoration among the lower classes. Within this context, overt representation of grief may have been less likely to trigger renewed and potentially unwanted feelings of grief among friends, family and neighbours that had experienced the same type of loss.

\section{Personal circumstance and choice in infant commemoration}

Although general patterning is evident in our data, the records of individual burials present a highly diverse picture of circumstances and motivations for infant commemoration. Only about 35 per cent of commemorated infant and young child burials were marked by their own gravestone. More commonly, infant deaths were recorded on monuments raised for a sibling or parent. Two-thirds of commemorations were made within a year of death, but they could take place from a year to as much as 36 years later. ${ }^{5}$ Delays of one to a few years might have been due to financial considerations, but delays of several years or decades suggest issues of unresolved grief, which might only have been satisfied with the creation of a lasting memorial.

A selection of family profiles also shows a wide range of social, demographic and residential circumstances. William and Elizabeth Whitechurch, for example, who farmed 300 acres in Harlton, commemorated their infant son Wilson, who died in 1852, on a monument erected three years later to mark the burial of their 11-year-old son James. Wilson was the last born of their nine children. Sydney Herbert Whitechurch, the grandson of William and Elizabeth, was also a farmer in Harlton. He and his wife Clara had six children and commemorated two who died as infants. The first, Edward, their first-born son, who died in 1895, was commemorated on a monument for his father's brother, Sydney Robert, who died 32 years earlier at age three. Their second son to die in infancy, Harold, who died in 1897, was commemorated on his own monument.

Similar variability characterizes the lowermiddle class. A monument in the Hinxton churchyard was raised to mark the burial of Evelyn Hopwood, who died as an infant in 1896. She was the middle of three children born to Mary and Harry Hopwood, a local butcher with long family ties to the community. Edward Macer, a publican and wheelwright, also had strong family ties to the village of Bourn from the 1830s through to the twentieth century. He and his wife Ursula had eight children. Three died in infancy, but only the first-born son Joseph, who died in 1853, is commemorated. His death is noted on the gravestone of his aunt, Mary Macer, who died in 1855. The other two infant children, William (d. 1864) and Lucy (d. 1869) are not recorded on any extant monument in Bourn or elsewhere in Cambridgeshire. George Negus, a carpenter, and his family were residentially far more mobile. He was born in Essex, but resided with his wife Ann in Fowlmere from sometime before 1859; the family moved to Surrey by 1871 and London by 1891. While living in Fowlmere they raised a monument to commemorate two of their sons, Charles, who died in 1860 at six months, and William, who died in 1862 at a year and a half. Their remaining four children all lived to adulthood.

The small number of labourers who commemorated their infant dead on gravestones shows a similar range of social and demographic circumstances. Benjamin Sparks, an agricultural labourer, and his wife Mary erected a monument in the Caldecote churchyard to mark the grave of their infant daughter Kate. She was the sixth of at least eight children, and died in 
1899. The Sparks family resided in multiple parishes in the nineteenth century. In contrast, Edward Whyatt, a farm labourer, born in Harlton in 1818, lived in the village all his life. He and his wife Frances, who was born in Haslingfield, had six children. Louisa, who died in 1861 at age 15, and Robert, the latest child, who died as an infant in 1860, are both commemorated on the monument of their father, who died in 1872. Finally, Mary and James Dean, a bricklayer, who maintained residence in the village of Swavesey throughout the latter half of the nineteenth century, commemorated their second child James, who died as an infant in 1852, on the monument erected for his sister Elizabeth, who died in 1866 at the age of 19 . One other child, a son, also named James, born in 1854, lived to adulthood and continued to work as a bricklayer in Swavesey into the twentieth century.

From these anecdotal examples, it appears the decision to commemorate infants was individual and personal. Sometimes it was made in the context of families with long community ties, other times by families who resided only a short while in the community in which their child was born and buried. Often it seems there was a family tradition of commemorating infant death, but in other cases this was extended to only a select infant. Commemoration could be focused on a monument specifically raised to mark the infant burial or could be added to the monument of a near or distant relative. These varied choices further stress the need to consider individual psychology as well as historical and socioeconomic circumstances in accounting for the way people coped with infant death.

\section{Discussion}

From our results we can outline a hierarchy of factors involved in the decision to commemorate infants. Sharp class-based differences in the numbers and proportions of adults and infants are clearly a function of economic means. Upper-middle class families had the means to provide a gravestone for burials, though this was not a universal practice. Some labourers also managed to raise stones to mark their dead, and as their economic conditions improved toward the end of the century there was a proportional rise in their use of stone monuments. But, though economic capacity may have set constraints and allowances for different burial treatments, this was not the determining factor in patterns and trends in infant commemoration. This is clear from both the lower rate for infants compared to adults for the upper-middle class and the proportionately greater increase in infant rates among the lower-middle and lower classes.

Differences in attachment styles and predilections toward loss- or restoration-oriented coping strategies for dealing with grief can account for why some, but not all infants were commemorated on gravestones. Restraint in memorializing infants is also consistent with social encouragement to focus less on the loss of an infant and more on the future, especially the needs of other children. The greater proportional commemoration of upper-middle-class infants could be attributed to greater economic means, but members of this class may also have experienced less social pressure to restrain their representation of grief because of a smaller class-based emotional community and fewer peers that could be adversely affected by their actions. The exceptional cases of infant commemoration, which always existed among the lower-middle and lower classes, point to individual loss-oriented responses regardless of limited economic means and potentially greater social constraint. The proportionately greater increase within these classes, which occurs in association with falling infant mortality rates and an especially dramatic reduction in how frequently infant death was experienced, points to relaxation of social constraints on grief representations.

Following the work of historians, it is unlikely that caregivers were more detached in the context of high mortality rates. There is also no change in infant commemoration among the upper-middle class with the decline in mortality. The probability of infant death appears to have had little if any independent effect on commemoration, apart from the contribution to the relative frequency with which infant death was experienced within different emotional communities. Social emulation could have had some weak effect on the increase in infant commemoration among the lower-middle and lower classes, but the rate of increase should have been commensurate across age categories if emulation was a determining factor.

\section{Conclusions: archaeology and the responses to grief}

Reactions to infant death are determined by individual psychology, social constraints and the experience of infant death within different emotional communities. There is little basis from archaeological evidence for assertions or counter-assertions of emotional attachment or detachment toward infants in the context of high mortality rates. Although attachment may be tempered in individual cases by the prospects for infant death due to circumstances affecting the health of the child and the well-being of its caregiver(s), there is no documented case in which such a response is so widespread as to be the primary determinant of a predominant mode of burial treatment. In extreme conditions, such as war, famine or plague, in which detachment may prevail to the point of altering emotional 
response to infant death and burial, there should be ample archaeological evidence from which to draw such a connection.

Variable propensities toward loss- or restorationoriented strategies for coping with the grief of infant death account for widespread patterns, exceptions and changes observed in burial treatments. Individuals with avoidant styles of attachment will be inclined to focus on restoration of their lives rather than marking the loss of an infant, as will others who are more restoration oriented in their coping strategies. An example might be men in cultural contexts in which male displays of emotion are more broadly discouraged. The potential for triggering repressed and unwanted grief could contribute to the maintenance of social sanction against overt representations, especially if the experience of infant death is common within an emotional community. The result is likely to be a smaller number of infants in public burial areas, potentially less investment in their burial and greater focus on burial within domestic contexts, where the representation of grief is private and unlikely to intrude on the feelings of others. McCafferty and McCafferty (2006) document this pattern in Postclassic Cholula, Mexico, where a small number of unadorned infants have been recovered among burials within a pyramid precinct, while infants, often with valuable grave goods, predominate among burials in an excavated domestic setting.

Individuals more secure in their attachment styles are more flexible in their response to the experience of grief and are likely to oscillate between loss and restoration coping strategies. They have a greater capacity to adjust their overt style of representing grief to conform to prevailing social and cultural standards. But attachment theory predicts there will always be some subset of individuals who will have more anxious attachment styles and be more loss oriented in the way they cope with grief. Archaeological observations of exceptional infant burials (Storey \& McAnany 2006, 67-70) can be explained as individual efforts to satisfy a personal need for loss-oriented grieving despite prevailing social standards. Alternatively, individuals from an elite emotional sub-community may be less socially constrained in their actions (e.g. McLaren 2011).

The Cambridgeshire study shows that individuals varied in their response to infant death, with only a small but variable proportion commemorating their loss on gravestones. Commemoration rates increase over time in association with declining infant mortality, but the connection is less obvious than generally imagined. The relative frequency of infant death rather than just the overall rate of infant mortality is the important factor that affects the extent of social constraint on mortuary representations. This conclusion is specific to the Cambridgeshire study, but the principles that underlie the interpretation can be generalized to account for changes in mortuary practices as a function of change in specific conditions relevant to the individual and social experience of grief, rather than to broader social and cultural constructions of the meaning and significance of infant death. ${ }^{6}$

Our purpose in documenting the varied propensity to commemorate infant death in Victorian Cambridgeshire was not just to demonstrate that differences existed between individuals or even to acknowledge a psychological basis for difference. Differences in the choice to commemorate children have been demonstrated elsewhere and have been cited to refute suggestions of broad uniformity in cultural sensibilities (Buckham 2003, 170-71; King 2000). Our goal was to show that those differences have a theoretical basis that can be generalized and used to explain not only pattern and variability in mortuary practice, but also the likelihood and direction of change. The more important aspect of attachment theory and the dual process model of bereavement is their capacity to account theoretically for tensions within and between individuals and between individuals and prevailing practice. Given a change in circumstances, such as declining mortality and relaxation of social constraints, that inherent tension can drive change in cultural practices.

We have not relied on textual sources, unavailable to most archaeologists, to explain changes in the material remains of mortuary practice, but have relied upon psychological theory which posits variable inclinations toward mortuary treatments that can be characterized broadly as more or less oriented toward the feelings of loss that occur with death. A further advantage of gravestones over textual sources is that they are the product of individual actions structured but not determined by changing social and historical circumstances. Changes in gravestone commemoration show clearly how variable psychological propensities and individual decisions in response to circumstances can lead to change in prevailing cultural standards. The alternative requires individuals to behave according to cultural constructs to which they make no contribution. Our focus highlights individuals as the agents of change, whether through their initiation or their acceptance of alternatives to normative practice.

Variability in attachment styles, flexibility and difference in the manner of coping with grief and variable overlapping emotional communities provide more than enough capacity for generating variability and change in burial patterns, especially given that 
attachment styles themselves may vary according to historical circumstances. In our study, demographic changes reduced the frequency of infant death, which led to the relaxation of social constraints on lossoriented representations of grief. Increasing incidence of death might be expected to provoke the opposite reaction, but there are potentially a wide range of factors that could influence individual and cultural attitudes regarding effective ways to cope with death and grief. The introduction of new rituals to strengthen the therapeutic effects of continuing bonds with the deceased is one possibility. Reliance on general psychological theory to explain aspects of mortuary practice does not diminish the specificity of practices in their cultural and historical contexts, but it does point toward the investigation of identifiable and relevant conditions that affect individual decision making.

\section{Notes}

1. Social constraint to protect the feelings of others, who have experienced similar loss, is exemplified in Wikan's $(1990,144)$ quotation from a middle-aged Balinese man, who fathered nine children and lost four, who said 'You must manage your heart so that you can forget your sadness. Otherwise, if you are sad, it may spread onto another ...'.

2. Attachment theory does not predict or prescribe detachment as the successful resolution of bereavement (Shaver \& Fraley 2008, 64-70). Bowlby (1980, 98, 135) noted the importance for many individuals in maintaining a persistent relationship with the dead and described the cultural emphasis on such practices as bringing comfort to widows in Japan. The therapeutic value of some forms of continuing bonds with the deceased is widely recognized (Field 2008), and maintenance of an ongoing relationship with the dead is understood as a predominant response to death in specific cultural and historical contexts (Bonanno \& Kaltman 1999, 764).

3. Conflict over appropriate forms of mourning behaviour is well documented. While some find comfort in graveside rituals and decorations or spontaneous roadside memorials, for example, others object and charge these actions represent failure to 'move on' in the grief process (Petersson 2010, 153-4; Woodthorpe 2011, 30). It is not always clear why the mourning practices of some provoke objections in others, but Petersson has suggested that unexpected encounters with Swedish roadside memorials may provoke repressed feelings of pain connected to previous experiences of death.

4. Our data do not include the burials or corresponding gravestone inscriptions in the Nonconformist cemeteries in Fowlmere, Harston, Ickleton, Over or Swavesey. Nonconformist burials and baptisms are also not used in the infant mortality estimates. A small number of burials associated with the Roman Catholic chapel in Kirtling and a small private burial ground in Great Wilbraham are also not included in this study. Church of England burials in late nineteenth century nondenominational cemeteries at Sawston, Stapleford and Swaffham Bulbeck were recorded in the church registers for those parishes. Monumental inscription records were available for Sawston and Stapleford, and all the church-registered burials were included in our analysis. Monument records were not available for the Swaffham Bulbeck cemetery; therefore 204 burials from this parish dating to 1886-1900 were excluded from the calculation of commemoration rates, though they were included in calculations of burial rates. A further 168 burials from various parishes were eliminated because we could not trace their age or occupation. Our sample for 18511900 consists of the remaining 13,658 Church of England registered burials for which age, occupation and, where applicable, monument inscription data were all available.

5. The length of time between death and commemoration was estimated based on the assumption that installation of new monuments or the addition of inscriptions to existing monuments typically occurred within a year of death, though there could be exceptions. If an inscription marking the death of an infant or young child was included on a monument for someone who died at a later date, then the delay between death and commemoration could be determined. Commemoration within a year of death was more common among the upper middle class, who had greater means to purchase new monuments and were more likely to have monuments for other family members available for the addition of new inscriptions, but delayed commemoration of infants and young children on a scale from several years to decades occurred among all social classes.

6. The same explanation can be used for developments in the commemoration of stillbirths in Western Europe and North America. Recent efforts to commemorate stillborn infants have been widely documented, with explanations citing a mix of general cultural trends and locally specific conditions, including technological change (ultrasound) and diminished authority of doctors in Belgium (Bleyen 2010), changing attitudes and hospital practices in Denmark (Sørensen 2011) and shifting policies and beliefs of the Catholic Church in the Netherlands (Peelen 2009). But the narratives describing the needs of some individuals in the present to represent their grief with ritual and lasting memorials and the relief experienced by individuals distressed by their lack of opportunity to do so in the past are remarkably similar from Europe to the UK (Scott 1999, 26) and Vancouver, British Columbia (Thomas 2006). This alone might suggest a more fundamental explanation and circumstance to account for these widespread developments. The relevant change that has occurred most recently, as with infant mortality in late Victorian England, is a dramatic decrease in the incidence of stillbirth. Statistics Canada (2001) figures show a 90 per cent 
reduction in stillbirths between 1928 and 1998 and current figures for Belgium are similarly low (Bleyen 2010, 82). It seems likely that more frequent occurrence of stillbirth in earlier decades promoted wider preference for constraint on overt expressions of grief and memorialization, regardless of the needs of some individuals. Earlier constraint was not the product of faceless authority, but was in line with wider individual and social preference for an alternative coping strategy. With precipitous decline in stillbirths the impact of individual grief on the wider community has lessened and social constraint is now being relaxed.

Aubrey Cannon Department of Anthropology McMaster University 1280 Main Street West Hamilton, ON L8S 4 L9 Canada

Email:cannona@mcmaster.ca

Katherine Cook Department of Archaeology University of York The King's Manor York Y01 7EP

$U K$

Email:krc508@york.ac.uk

\section{References}

Archer, J., 1999. The Nature of Grief: The Evolution and Psychology of Reactions to Loss. London: Routledge.

Ariès, P., 1962. Centuries of Childhood (trans. R. Baldick). New York (NY): Vintage Books.

Armstrong, W.A., 1972. The use of information about occupation, in Nineteenth-Century Society: Essays in the Use of Quantitative Methods for the Study of Social Data, ed. E.A. Wrigley. Cambridge: Cambridge University Press, 191-310.

Binford, L.R., 1971. Mortuary practices: their study and their potential, in Approaches to the Social Dimensions of Mortuary Practices, ed. J.A. Brown. (Memoirs of the Society for American Archaeology 25.) Washington (DC): Society for American Archaeology, 6-29.

Bleyen, J., 2010. The materialities of absence after stillbirth: historical perspectives, in The Matter of Death: Space, Place and Materiality, eds. J. Hockey, C. Komaromy $\&$ K. Woodthorpe. Basingstoke: Palgrave Macmillan, 69-84.

Bonanno, G.A., \& S. Kaltman, 1999. Toward an integrative perspective on bereavement. Psychological Bulletin $125,760-76$.

Bowlby, J., 1969. Attachment and Loss, Vol. 1: Attachment. New York (NY): Basic Books.

Bowlby, J., 1980. Attachment and Loss, Vol. 3: Loss: Sadness and Depression. New York (NY): Basic Books.
Buckham, S., 2003. Commemoration as an expression of personal relationships and group identities: a case study of York Cemetery. Mortality 8, 160-75.

Cannadine, D., 1981. War and death, grief and mourning in modern Britain, in Mirrors of Mortality: Studies in the Social History of Death, ed. J. Whaley. London: Europa, 187-242.

Cannon, A., 1989. The historical dimension in mortuary expressions of status and sentiment. Current Anthropology 30, 437-58.

Cannon, A., 2005. Gender, agency, and mortuary fashion, in Interacting with the Dead: Perspectives on Mortuary Archaeology for the New Millennium, eds. G.F.M. Rakita, J.E. Buikstra, L.A. Beck \& S.R. Williams. Gainesville (FL): University Press of Florida, 41-65.

Carroll, M., 2011. Infant death and burials in Roman Italy. Journal of Roman Archaeology 24, 99-120.

Collis, J., 1977. Owslebury (Hants) and the problem of burials on rural settlements, in Burial in the Roman World, ed. R. Reece. (CBA Research Report 22.) London: Council for British Archaeology, 26-38.

Crawford, S., 2011. The disposal of dead infants in AngloSaxon England from c. 500-1066: an overview, in (Re)Thinking the Little Ancestor: New Perspectives on the Archaeology of Infancy and Childhood, eds. M. Lally \& A. Moore. (BAR International Series S2271.) Oxford: Archaeopress, 75-84.

Deetz, J., 1977. In Small Things Forgotten: The Archaeology of Early American Life. New York (NY): Doubleday.

Dye, N.S. \& D.B. Smith, 1986. Mother love and infant death, 1750-1920. Journal of American History 73, 329-53.

Field, N.P., 2008. Whether to relinquish or maintain a bond with the deceased. in Handbook of Bereavement Research and Practice: Advances in Theory and Intervention, eds. M.S. Stroebe, R.O. Hansson, H. Schut \& W. Stroebe. Washington (DC): American Psychological Association, 113-32.

Gassin, E.A., 2010. Cultural variations in the link between attachment and bereavement, in Attachment: Expanding the Cultural Connections, eds. P. Erdman \& K.-M. Ng. New York (NY): Routledge, 71-87.

Golden, M., 1988. Did the ancients care when their children died? Greece and Rome 35, 152-63.

Gregory, I.N., 2008. Different places, different stories: infant mortality decline in England and Wales, 1851-1911. Annals of the Association of American Geographers 98, 773-94.

Hertz, R., 1960 [1907].Death and the Right Hand (trans. R. Needham \& C. Needham). Glencoe (IL): Free Press.

Horn, P., 1984. The Changing Countryside in Victorian and Edwardian England and Wales. London: AthlonePress.

Howkins, A., 1991. Reshaping Rural England: A Social History 1850-1925. London: HarperCollins Academic.

Hrdy, S.B., 1999. Mother Nature: Maternal Instincts and How They Shape the Human Species. New York (NY): Ballantine. 
Jalland, P., 1996. Death in the Victorian Family. Oxford: Oxford University Press.

Joyce, R.A., 2001. Burying the dead at Tlatilco: social memory and social identities, in Social Memory, Identity, and Death: Anthropological Perspectives on Mortuary Rituals, ed. M.S. Chesson. (Archaeological Papers 10.) Washington (DC): American Anthropological Association, 12-26.

King, M., 2000. Commemoration of infants on Roman funerary inscriptions, in The Epigraphy of Death: Studies in the History and Society of Greece and Rome, ed. G.J. Oliver. Liverpool: Liverpool University Press, 117-54.

Leavitt, J., 1996. Meaning and feeling in the anthropology of emotions. American Ethnologist 23, 514-39.

Little, B.J., K.M. Lanphear \& D.W. Owsley, 1992. Mortuary display and status in a nineteenth-century AngloAmerican cemetery in Manassas, Virginia. American Antiquity 57, 397-418.

Macfarlane, A., 1981. Death and the demographic transition: a note on English evidence on death 1500-1750, in Mortality and Immortality: The Anthropology and Archaeology of Death, eds. S.C. Humphreys \& H. King. London: Academic Press, 249-59.

McCafferty, G.G. \& S.D. McCafferty, 2006. Boys and girls interrupted: mortuary evidence of children from Postclassic Cholula, Puebla, in The Social Experience of Childhood in Ancient Mesoamerica, eds. T. Ardren \& S.R. Hutson. Boulder (CO): University Press of Colorado, 25- $\$ 352$.

McLaren, D. 2011. Where have all the flowers gone? Bronze Age children's burials in south east England: initial thoughts, in (Re)Thinking the Little Ancestor: New Perspectives on the Archaeology of Infancy and Childhood, eds. M. Lally \& A. Moore. (BAR International Series S2271.) Oxford: Archaeopress, 85-99.

Meskell, L., 1999. Archaeologies of Social Life: Age, Sex, Class et cetera in Ancient Egypt. Oxford: Blackwell.

Middleton, D.R., 1989. Emotional style: the cultural ordering of emotions. Ethos 17, 187-201.

Mikulincer, M. \& P.R. Shaver, 2008. An attachment perspective on bereavement, in Handbook of Bereavement Research and Practice: Advances in Theory and Intervention, eds. M.S. Stroebe, R.O. Hansson, H. Schut \& W. Stroebe. Washington (DC): American Psychological Association, 87-112.

Mytum, H., 2009. Mortality symbols in action: Protestant and Catholic memorials in early-eighteenth-century West Ulster. Historical Archaeology 43, 160-82.

Parker Pearson, M., 1982. Mortuary practices, society and ideology: an ethnoarchaeological study, in Symbolic and Structural Archaeology, ed. I. Hodder. Cambridge: Cambridge University Press, 99-113.

Peelen, J., 2009. Reversing the past: monuments for stillborn children. Mortality 14, 173-86.

Peppers, L.G. \& R.J. Knapp, 1980. Motherhood and Mourning. New York (NY): Praeger.
Petersson, A. 2010. The production of a memorial place: materializing expressions of grief, in Deathscapes: Spaces for Death, Dying, Mourning and Remembrance, eds. A. Maddrell \& J.D. Sidaway. Farnham: Ashgate, 14159.

Pollock, L.A., 1983. Forgotten Children: Parent-Child Relations from 1500-1900. Cambridge: Cambridge University Press.

Quilter, J., 1989. Life and Death at Paloma: Society and Mortuary Practices in a Preceramic Peruvian Village. Iowa City (IA): University of Iowa Press.

Robinson, M., L. Baker \& L. Nackerud, 1999. The relationship of attachment theory and perinatal loss. Death Studies 23, 257-70.

Rosenblatt, P.C., 1983. Bitter, Bitter Tears: Nineteenth-Century Diarists and Twentieth Century Grief Theories. Minneapolis (MN): University of Minnesota Press.

Rosenblatt, P.C., 2008. Grief across cultures: a review and research agenda, in Handbook of Bereavement Research and Practice: Advances in Theory and Intervention, eds. M.S. Stroebe, R.O. Hansson, H. Schut, \& W. Stroebe. Washington (DC): American Psychological Association, 207-22.

Rosenblatt, P.C. \& L. Hammer Burns, 1986. Long-term effects of perinatal loss. Journal of Family Issues 7, 237-53.

Rosenwein, B.H., 2002. Worrying about emotions in history. American Historical Review 107, 821-45.

Rubertone, P.E., 2001. Grave Undertakings: An Archaeology of Roger Williams and the Narragansett Indians. Washington (DC): Smithsonian Institution Press.

Russell, J.C., 1985. The Control of Late Ancient and Medieval Population. Philadelphia (PA): American Philosophical Society.

Saxe, A.A., 1970. Social Dimensions of Mortuary Practices. Unpublished PhD dissertation, University of Michigan.

Scheper-Hughes, N., 1992. Death Without Weeping: The Violence of Everyday Life in Brazil. Berkeley (CA): University of California Press.

Scott, E., 1999. The Archaeology of Infancy and Infant Death. (BAR International Series S819.) Oxford: Archaeopress.

Shaver, P.R. \& R.C. Fraley, 2008. Attachment, loss, and grief. In Handbook of Attachment: Theory, Research, and Clinical Applications (2nd edition), eds. J. Cassidy \& P.R. Shaver. New York (NY): Guilford Press, 48-77.

Shorter, E., 1975. The Making of the Modern Family. New York (NY): Basic Books.

Sørensen, T.F., 2011. Sweet dreams: biographical blanks and the commemoration of children. Mortality 16, 161-75.

Statistics Canada. 2001. The Daily. Wednesday 14 March 2001. http://www.statcan.gc.ca/daily-quotidien/ 010314/dq010314b-eng.htm

Stearns, P.N. \& M. Knapp, 1996. Historical perspectives on grief, in The Emotions: Social, Cultural and Biological Dimensions, eds. Rom Harré \& W. Gerrod Parrott. London: Sage, 132-50. 
Stearns, P.N. \& C.Z. Stearns, 1985. Emotionology: clarifying the history of emotions and emotional standards. American Historical Review 90, 813-36.

Stone, L., 1977. The Family, Sex and Marriage in England 15001800. London: Weidenfeld\& Nicolson.

Storey, R. \& P.A. McAnany, 2006. Children of K'axob: premature death in a Formative Maya village, in The Social Experience of Childhood in Ancient Mesoamerica, eds. T. Ardren \& S.R. Hutson. Boulder (CO): University Press of Colorado, 53-72.

Strange, J.-M., 2005. Death, Grief and Poverty in Britain, 18701914. Cambridge: Cambridge University Press.

Stroebe, M. \& H. Schut, 1999. The dual process model of coping with bereavement: rationale and description. Death Studies 23, 197-224.

Stroebe, M., H. Schut \& W. Stroebe, 2005. Attachment in coping with bereavement: a theoretical integration. Review of General Psychology 9, 48-66.

Tarlow, S., 1999. Bereavement and Commemoration: An Archaeology of Mortality. Oxford: Blackwell.

Tarlow, S., 2000. Emotion in archaeology. Current Anthropology 41, 713-46.

Thomas, S., 2006. A grief delayed. Vancouver Courier. http:/ / www.elac.bc.ca/PDF/MVC/MVC\%20$\% 20$ Infant $\% 20$ Graves $\% 20$ Implementation $\% 20-\mathrm{A} \%$ 20grief\%20delayed.pdf

Ucko, P.J., 1969. Ethnography and archaeological interpretation of funerary remains. World Archaeology 1, 262-80.

Wijngaards-de Meij, L., M. Stroebe, H. Schut, W. Stroebe, J. van den Bout, P.G.M. van der Heijden \& I. Dijkstra, 2008. Parents grieving the loss of their child: interdependence in coping. British Journal of Clinical Psychology 47, 31-42.

Wikan, U., 1988. Bereavement and loss in two Muslim communities: Egypt and Bali compared. Social Science and Medicine 27, 451-60.
Wikan, U., 1990. Managing Turbulent Hearts: A Balinese Formula for Living. Chicago (IL): University of Chicago Press.

Winter, J.M., 1982. The decline of mortality in Britain 18701950, in Population and Society in Britain 1850-1980, eds. T. Barker \& M. Drake. New York (NY): New York University Press, 100-120.

Woodthorpe, K., 2011. Using bereavement theory to understand memorializing behaviour. Bereavement Care 30, 29-32.

Wrigley, E.A. \& R.S. Schofield, 1981. The Population History of England 1541-1871: A Reconstruction. Cambridge (MA): Harvard University Press.

\section{Author biographies}

Aubrey Cannon is Professor of Anthropology at McMaster University. His research interests include mortuary archaeology and the archaeology of the Pacific Northwest Coast of North America. He recently edited Structured Worlds: The Archaeology of Hunter-Gatherer Thought and Action, Equinox (2011) and, with Madonna L. Moss, The Archaeology of North Pacific Fisheries, University of Alaska Press (2011). He is coeditor, with Liam Frink, of the series Archaeology of Colonialism in Native North America, University of Arizona Press.

Katherine Cook is a PhD student at the University of York, where she is researching family and colonialism in England and Barbados through the study of historical cemeteries. She has studied cemeteries in Hamilton, Ontario, and Victoria, British Columbia, and is the author of 'A different kind of afterlife: the cultural biography of headstones', a paper in Identity Crisis: Archaeological Perspectives on Social Identity (2011). 